\title{
Double helical forms of poly(A): possible involvement in biological processes
}

\author{
M. I. Zarudnaya \\ Institute of Molecular Biology and Genetics of National Academy of Sciences of Ukraine \\ 150 vul. Acad. Zabolotnoho, Kyiv, 03143, Ukraine
}

In this short review unique conjormational possibilities of polyadenylic acid are described. The possibility of double oligo(A)-helices formation in RNA biological systemis has been discussed. It is proposed that the basis for stabilization effect of ELAV-like proteins is their ability to form internal double oligo(A)-helices in the poly $(A)$ tails of specific mRNAs

Are double helical forms of poly(A) used in biological processes? Most of mRNAs in all living organisms contain a $3^{\prime}$ terminal tract of adenosine residues, the so-called poly(A) tail [1]. It is evident that mRNA poly(A) tails potentially possess all the properties of polyadenylic acid. Depending on protonation extent of adenines (at the NI position) poly(A) can exist in various forms: single-stranded form, three different double helical forms and «frozen» form [2-8]. We label these forms respectively as $S, D, D_{p}, D^{\prime}$ and $F$ forms. (Double helical forms of poly (A) don't have the fixed names. Besides, such their terms as B and A forms, which are often mel, cause difficulty because one draws a parallel with similar labelling of DNA and RNA structures.)

Under physiological ionic strength at neutral and alkaline $\mathrm{pH}$ poly (A) exists in single-stranded form. Poly (A) tails of mRNA probably exist in the cell just in this form. Poly (A) double-stranded helices are formed at this ionic strength at $\mathrm{pH} \sim 6$ [9]. But methylation of riboses [10] or bases [11, 12] in polyadenylic acid results in a shift in $\mathrm{pK}_{a}$ of formation of double-stranded helices towards alkaline region. The most significant shift occurs as a result of adenine methylation in the position N1 [11]. In this case poly(A) double-stranded helices are formed in $0.15 \mathrm{M} \mathrm{NaCl}$ at $\mathrm{pH} \approx 9.1$.

In vivo $\mathrm{pK}_{\alpha}$ of adenine protonation in RNA could

(C) M. I. ZARUDNAYA, 1999 be modulated towards physiological pH not only by chemical modification or $\mathrm{pH}$ local change but also by interactions between oligo(A)-tracts and appropriate proteins. In particular, adenine protonation may occur on account of proton transfer from acidic amino acids of protein. For example a proton transfer from amino acid carboxylic group to nucleotide base is characteristic of many complexes which model point proteinnucleic acid contacts [13, 14]. The protonation of cytosines and adenosines inside tymoviral virions was observed $[15,16]$. It is proposed that it may be a result of direct interaction between bases and acidic amino acid residues of the coat protein [17]. Taking into consideration all these facts we have proposed that double oligo(A)-helices may be formed in a cell $[18,19]$.

Our recent research of conformational transitions in poly (A) by proton buffer capacity method 18] made it possible to describe the process of poly(A) double helices formation from single-stranded structures in details. It turned out that $\mathrm{pK}_{\alpha}$ for highly co-operative formation of poly (A) double-stranded D and $D_{P}$ forms are very similar. At $T>10{ }^{\circ} \mathrm{C}$ the difference in their values does not exceed 0.3 units of $\mathrm{pH}[8]$.

The main distinction between these forms is the degree of stability of the helices. Each adenine base in $\mathrm{D}_{\mathbf{p}}$ form is involved into three hydrogen bonds: two $\mathrm{N}_{6} \mathrm{H} . . . \mathrm{N}_{7}$ bonds and the bond between adenine amino group and phosphate oxygen atom [20]. In D form hydrogen bonds between the bases are the same as in 
$D_{p}$ form but in this form there are no bonds between the bases and phosphates [5]. $D^{\prime}$ form is formed at $\mathrm{pH}-5$ as a result of the $\mathrm{D}$ form conformational change $[5,8]$.

The existence of three kinds of double-stranded forms is a unique property of poly (A), other homopolyribonucleotides do not form different double helices. It is remarkable that $D$ and $D_{P}$ forms of poly (A) which differ in their stability can exist simultaneously under particular conditions. It is diffucult to imagine that this property of polyadenylic acid is not utilized in any biological processes.

In the recent review [21] dedicated to the conference on RNA moleçular biology it was emphasized that in spite of the title of the conference the participants spoke mainly about proteins and not about RNA. But if one takes into consideration at least poly(A) conformational possibilities, the contribution of the RNA per se into mechanisms of its functioning in the cell may turn out to be greater than one assumes at present.

The existence of different double-stranded helices is not a single unique property of poly (A). Possibly this homopolyribonucleotide is the only one forming «frozen» ( $F$ ) form. It is unclear at present whether poly $(C)$ can form such a structure. According to our data [6] poly $(G)$ and poly (U) do not adopt the $F$ form. «Frozen» form was discovered by Janik et al. [4]. They suggested that this structure consists of the mismatched strands and randomly distributed short double-stranded regions. Our experiments have shown that the direct addition of acid into poly(A) solution (regardless of the method of adding it) always results in arise of the «frozen» form $[6,8]$. To prevent its formation, it is necessary to dialyze solutions of poly(A) single-stranded form against buffers of desired $\mathrm{pH}$. Besides, the $\mathrm{F}$ form can be disrupted by means of the short duration heating [4, 6].

By, means of the electrophoretic method we have demonstrated that the $F$ form represents bulky structures of different sizes [6]. We supposed [19] that double helices random formation between the parts of the same molecule (internal double helix) and simultaneously with neighbouring molecules may be responsible for the appearance of the «frozen» form.

We believe that similar formation of the internal double helices during folding of RNA poly(A)-tracts may take place in a cell also.

mRNA poly(A) tails take part in a number of intracellular processes such as mRNA stabilization and degradation, translation initiation and possible mRNA nuclear transport and mRNA localization [22]. But mechanisms of poly(A)-tracts' involvement into these processes have not yet been determined. Can taking into consideration the polyadenylic acid conformational possibilities, exactly its property to form double helices, including internal ones, be useful in the determining of these mechanisms?

Having analyzed the previous research material, we supposed that some biological processes might occur with the participation of the double oligo(A)helices $[18,19]$, for example such processes as the termination of polyadenylation and poly (A)-binding protein (PAB) autoregulation. According to our model $[18,19]$ the formation, during the elongation of synthesizing poly(A) tail, of internal double helix close to the RNA-protein complex which carries out polyadenylation reaction results in destroying of this complex and synthesis termination. So poly(A) tails length control occurs.

According to our other model the formation of internal double helix inside the A-rich sequence in the $5^{\prime}$ untranslated region $\left(5^{\prime}\right.$ UTR) of $\mathrm{PAB}$ mRNA in the case of $\mathrm{PAB}$ excess in cytoplasm may be responsible for repression of $\mathrm{PAB}$ synthesis.

To author's knowledge, our hypothesis on functioning of double oligo(A)-helices in cell has not yet been proved experimentally. But not so long ago an article was published in which it has been proposed that ELAV (embryonic lethal abnormal visual)-like proteins possibly recognize a secondary or tertiary structure of poly(A) [23]. The second part of the present work is devoted to the discussion of this article.

Do ELAV-like proteins cause structural transitions in poly(A)? ELAV-like proteins stabilize specific mRNAs by means of the interaction with AU-rich elements (AREs) in their $3^{\prime}$ untranslated region ( $3^{\prime}$ UTR) [23-25]. Ma et al. [23] have shown that the human ELAV-like proteins $\mathrm{HuD}$ and $\mathrm{HuR}$ can also bind to poly (A). HuC protein which belongs to this family has also poly(A)-binding ability [26]. It is supposed $[23,26]$ that this ability is probably a feature of all the ELAV-like proteins.

However the proteins of ELAV group bind to poly(A) quite differently from the various PABs. Though in the case of PAB I and PAB II the minimal sizes of the binding site are about 12 and 10 nucleotides respectively $[27,28]$ ElAV-Iike proteins prefer the polymers longer than 70 nucleotides [23]. Reactivity of ELAV-like proteins increases with the increase of the polymer length, reaching saturation at $\operatorname{poly}(\mathrm{A})_{300}$. The interaction is not co-operative. Ma et al. were forced to suppose that ELAV-like proteins recognize a secondary or tertiary structure that is only evident in long chain poly (A).

ELAV-like proteins contain three characteristic 
RNP2/RNPI-type [29] binding motifs. The first two domains specifically bind to AREs and the third one binds to poly (A) $[23,26]$.

$\mathrm{HuR}$ is expressed in all proliferating cells. The results of Fan et al. [24] suggest that the binding of this protein both to the ARE and poly(A) tail is required for effective mRNA stabilization. Stabilization mechanism is not clear at present. Ma et al. [23] suppose that ELAV-like proteins inhibit the action of a specific endonuclease that recognizes ARE. Association of the ELAV-like proteins with both the AU-rich element and the poly (A) tail is necessary for effective mRNA protection. As an alternative variant the authors suppose that «ELAV-like proteins may sequester the poly(A) tail of a target mRNA, with a consequent inhibitory effect on a poly(A) exonuclease activity».

Fan et al. [24] think that the experimental data available at present do not permit to determine whether HuR is stabilizing or destabilizing protein. In the second case, as the authors suppose, HuR may be a part of a large protein complex which performs degradation of ARE-containing mRNAs. If other factors in this complex are limited, then overexpression of $\mathrm{HuR}$ results in precluding assembly of the active degradation complex. This causes the stabilizing effect.

It has been demonstrated [25] that the elevation of $\mathrm{HuR}$ in the cytoplasm has little effect on the poly (A) shortening step but delays onset of decay of the RNA body and slows down its subsequent decay. The authors suppose that $\mathrm{HuR}$ might participate in the mRNA deadenylation and its subsequent return to the nucleus ( $\mathrm{HuR}$ is a shuttling protein $[24,25]$ ) might then allow decay of the RNA body to occur, thus preventing a timely return of HuR to the nucleus causes the stabilizing effect.

As for our opinion [30] we prefer the alternative model of Ma et al. [23] and taking into consideration that ELAV-like proteins specifically bind only to long chain poly (A) tails, we believe that the «sequestering» of mRNA poly (A) tail which has been proposed in this work is the formation of the internal double helix as it is demonstrated in fig 1 . According to this model the most part of mRNA poly (A) tails is available for poly(A) nuclease action and the HuR overexpression must not affect the deadenylation rate as it is observed in [25]. Inhibition of mRNA decay will be result from poly(A) nuclease inability to degrade that part of poly (A) tail which is organized into the double oligo(A)-helix.

It is worth to emphasize that our assumption of the internal double helix formation adjacent to the transcribing part of mRNA is made to satisfy data of

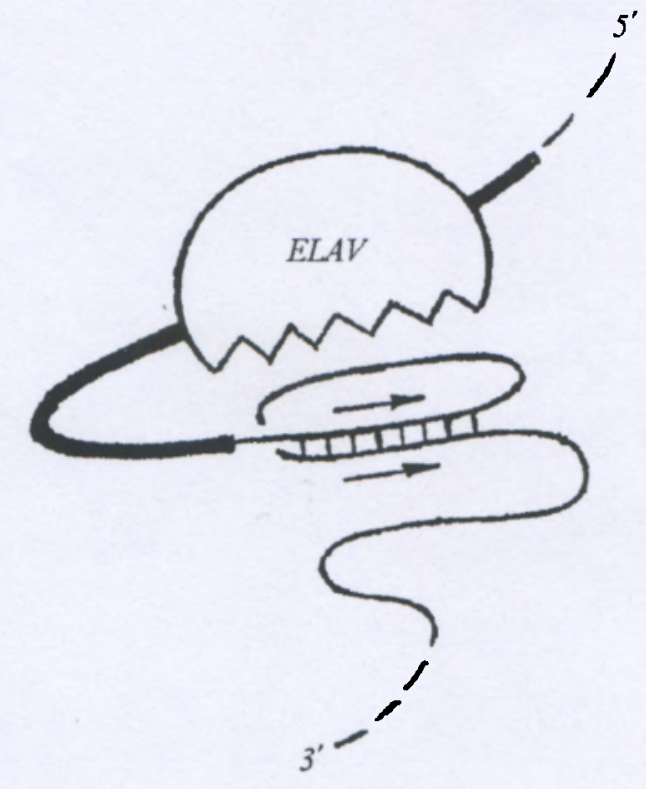

Fig. 1. The scheme of double oligo(A)-helix formation upon binding ELAV-like protein to ARE-containing mRNA. The transcribing part of the mRNA and the poly(A) tail are depicted by thick and thin lines respectively. $5^{\prime} \leftrightarrow 3^{\prime}$ direction of the RNA chain is shown by the arrow

Peng et al. [25]. It is possible that the double helices are formed in the different parts of poly (A) tail but the most stable helix is formed just in this position.

As was mentioned above the affinity of $H u R$ for poly (A) increases with the poly (A) size increase from 70 to 300 nucleotides [23] (it is necessary to note that HuR is able to bind to poly (A) of lesser sizes but at great excess of protein [23]). The dependence of such kind may arise from the stability dependence of double oligo(A)-helices from the length of their constituent oligomers. It was shown [31] that thermal stability of double oligo(A)-helices sharply grows as chain length increases from $6-8$ residues to 15 residues, beyond this size stability increases relatively slowly.

25-30 nucleotides is probably minimal size for oligo(A)-tract to fold with formation of the internal double helix. In this case double helix length does not exceed 10 nucleotides and such helix will be much less stable than the internal double helix some dozens nucleotides in length which may be formed at folding of polymer few hundred nucleotides long.

Fig. 2, $a, b$ probably depict the most simple schemes of poly(A) internal double helices for- 


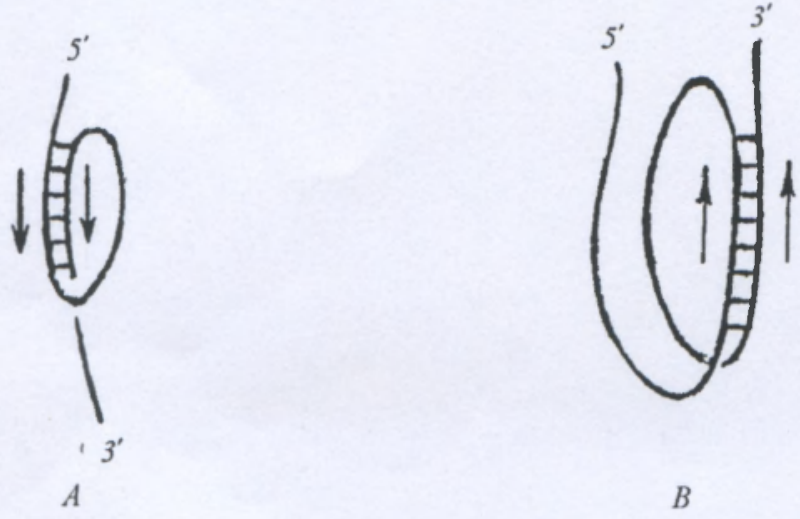

Fig. 2. The schemes of internal double helices formation in poly(A). $5^{\prime} \rightarrow 3^{\prime}$ direction of the RNA chain is shown by the arrows

mation. In the fig. 2, $a$ double helix is formed at the beginning of the second wind of the single-stranded polymer and in the fig. $2, b$ it is formed at the end of such wind.

We proposed that during the termination of polyadenylation the internal double helix is formed in the case of yeast (poly (A) tails have the length of $\sim 70$ nucleotides) in accordance with the first scheme and in the case of animals (poly (A) tails have a length of -250 nucleotides) in accordance with the second. scheme. We also suggest that in accordance with the first scheme folding of the A-rich tract in the 5' UTR of PAB mRNA in the process of PAB autoregulation can occur. This tract has a length of $\sim 70$ nucleotides [32].

Is it accidental that the poly(A) tail length of yeast and the length of A-rich tract in the 5' UTR of PAB mRNA coincide with the minimal poly (A) length at which the ELAV-like proteins bind to this polymer and poly(A) tails length of animals coincides with poly(A) length at which HuR binding is the most effective? We believe this is not the case. Most probably, the coincidence derives from the same process which provides the basis for polyadenylation termination, autoregulation of PAB synthesis and stabilization of ARE-containing mRNA by ELAV-like proteins, namely, formation of the internal double helix on folding of poly (A)-tracts. In some cases the double-stranded helices are formed according to the most simple scheme (fig. 2, $a$ ), in other cases the formation of the most stable long helices takes place.
M. I. Зарудıа

Двоспіральні форми полі(A): можливе втэгнення в біологічи процеси

Резюме

В огляді стисло описано унікальні конформаційні можливості поліаденілової кислоти. Обмірковано питання про можливімь утворення подвійних оліго(A)-спіралей в PHК у біологіџних системах. Висловлено припуцення про те. ицо в основі стабілізаційноі дії ELAV-подібних білків лежить їня здатність стимулювати утворення внутріиніх подвійни олісо (A)-cniралей в полі( $A)$-хвостах специфічних мРНК.

\section{М. И. Зарудная}

Двухспиральные формы поли(А): возможное вовлечение в биологические процессы

Резюме

В обзоре кратко описаны уникальные конформационные возможности полиадениловой кислоты. Обсужден вопрос о возможности образования двойных олиго (A)-спиралей в РНК в биолосических системах. Высказано предположение о том, что в основе стабилизируюццего действия ELAV-подобных белков лежит их способность вызывать образование внутренних двойных олиго $(A)$-спиралей в поли( $A)$-хвостах специфических MPIIK

\section{REFERENCES}

1. Manley J. L. Messenger RNA polyadenylylation: A universal

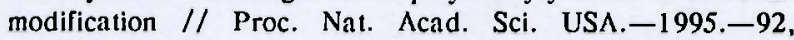
N 6.-P. 1800-1801.

2. Adler A. J., Grossman L. Fasman G. D. Polyriboadenylic and polydeoxyriboadenylic acids. Optical rotatory studies of $\mathrm{pH}$ dependent conformations and their relative stability // Biochemistry. -1969. - 8, N 9.-P. 3846-3859.

3. Finch $J$. T., Klug $A$. Two double helical forms of polyriboadenylic acid and the pH-dependent transition between them // J Mol. Biol. - 1969.-46, N 3.-P. 597-598.

4. Janik B., Sommer R. G., Bobst A. M. Polarography of polynucleotides. II. Conformations of poly (adenylic acid) at acidic $\mathrm{pH} / /$ Biochim. et biophys. acta.-1972. $-281, \mathrm{~N} 2$.P. $152-168$.

5. Ierner D. B., Kearns D. R. Proton and phosphorus NMR investigation of the conformational states of acid polyadenylic double helix // Biopolymers.-1981.-20, N 4.-P. 803816.

6. Zarudnaya $M$. I., Zheltovskii $N$. V. Affinity electrophoresis investigation of the interaction between homopolyribonucleotides and the lysine ester dication // Mol. Biol._-1992.-26, N 1, pt 2.-P. 87-93, translated from Molekulyarnaya Biologia.-1992. -26, N 1.-P. 110-117.

7. Zarudnaya M. I., Zheltovskii N. V. Electrophoretic analysis of conformational transitions in poly(A) at acidic pH $/ /$ Mol. Biol. - 1995.-29, N 5.-P. 611-615, translated from Molekulyarnaya Biologia.-1995.-29. N 5.-P. 1040-1047.

8. Zarudnaya $M$. I. Study of conformational transitions in poly $(\Lambda)$ by the buffer capacity technique // Mol. Biol.-1998.-32, N 3.-P. 417-422, translated from Molekulyarnaya Biologia. -1998. - 32, N 3.-P. 508-514.

9. Holcomb D. N., Timasheff $S$. N. Temperature dependence of the hydrogen ion equilibria in poly(riboadenylic acid) // Biopolymers. - 1968.-6, N 4.-P. 513-529.

10. Bobst A. M., Rottman F., Cerutti $P$. A. Effect of the methylation of the 2 '-hydroxyl groups in polyadenylic acid on 
its structure in weakly acidic and neutral solutions and on its capability to form ordered complexes with polyuridylic acid // J. Mol. Biol.-1969.-46, N 2.-P. 221-234.

11. Thrierr $C$., Leng $M$. A study of methylated polyadenylic acid // Eur. J. Biochem. -1971.-19, N 1.-P. 135-142.

12. Ikehara M., Hattori M., Fukui T. Synthesis and properties of poly (2-methyladenylic acid). Formation of a poly (A) - poly(U) complex with hoogsteen-type hydrogen bonding // Eur. J. Biochem.-1972.-31, N 2.-P. 329-334.

13. Samijlenko S. P., Kolomiets I. M., Kondratyuk I. V., Stepanyugin $A$. V. Model considerations on physico-chemical nature of protein-nucleic acid contacts through amino acid carboxylic groups: spectroscopic data // Biopolimery i kletka.-1998.14, N 1.-P. 47-53.

14. Kondratyuk I. V. Investigation of physico-chemical nature of elementary processes of molecular recognition by NMR, vibrational spectroscopy and computer simulation. - Kyiv: Ph. D. Thesis, 1996. - 19 p.

15. Hartman K. A., McDonald-Ordzie P. E., Kaper J. M., Prescott B., Thomas G. J., Jr. Studies of virus structure by laser-Raman spectroscopy. Turnip yellow mosaic virus and capsids // Biochemistry.-1978. -17, N 11.-P. 2118-2123.

16. Prescott B., Sitaraman K., Argos P., Thomas G. J., Jr. Protein-RNA interactions in belladonna mottle virus investigated by laser Raman spectroscopy // Biochemistry.1985.-24, N 5.-P. 1226-1231.

17. Hellendoorn K., Michiels P. J. A., Buitenhuis R., Pleij C. W. $A$. Protonatable hairpins are conserved in the $5^{\prime}$-untranslated region of tymovirus RNAs // Nucleic Acids Res.-1996.-24, N 24.-P. 4910-4917.

18. Zarudna $M$. I. The formation of poly (A) double-stranded helices and their possible role in biological processes // 2-nd Meeting UBS.-Kharkiv, 1998.-P. 11.

19. Zarudna $M$. I., Hovorun D. $M$. Structural transitions in polyadenylic acid: possible molecular mechanisms of mRNA poly (A) tails functioning // Dopovidi NAN Ukrainy.-1998.N 12.-P. 155-160.

20. Rich A., Davies D. R., Crick F. H. C., Watson J.D. The molecular structure of polyadenylic acid // J. Mol. Biol.1961.-3, N 1.-P. 71-86.

21. Birih $K . R$. Conference «Molecular biology of RNA: translation, stability and localization of mRNA»// Rus. J. Bioorg. Chem.-
1998.-24, N 6.-P. 476-478.

22. Sachs A., Wahle E. Poly $(\mathrm{A})$ tail metabolism and function in eucaryotes // J. Biol. Chem. -1993.-268, N 31.P. 22955-22958.

23. $M a W .-J$., Chung $S$., Furneaux $H$. The Elav-like proteins bind to AU-rich elements and to the poly(A) tail of mRNA // Nucleic Acids Res. - 1997.-25, N 18.-P. 3564-3569.

24. Fan X. C., Steitz J. A. Overexpression of HuR, a nuclearcytoplasmic shuttling protein, increases the in vivo stability of ARE-containing mRNAs // EMBO J.-1998.-17, N 12. P. 3448-3460.

25. Peng S. S.-Y., Chen C.-Y. A., Xu N., Shyu A.-B. RNA stabilization by the AU-rich element binding protein, HuR, an ELAV protein // EMBO J.-1998.-17, N 12.-P. 34613470 .

26. Abe R., Sakashita E., Yamamoto K., Sakamoto II. Two different RNA binding activities for the AU-rich element and the poly (A) sequence of the mouse neuronal protein $\mathrm{mHuC} / /$ Nucleic Acids Res.-1996. - 24, N 24.-P. 4895-4901.

27. Sachs A. B., Davis R. W. Kornberg R. D. A single domain of yeast poly(A)-binding protein is necessary and sufficient for RNA binding and cell viability // Mol. Cell. Biol. -1987.-7, N 9.-P. 3268-3276.

28. Nemeth A., Krause S., Blank D., Jenny A., Jeno P., Lustig $A$., Wahle $E$. Isolation of genomic and cDNA clones encoding bovine poly $(\mathrm{A})$ binding protein II // Nucleic Acids Res.1995.-23, N 20.-P. 4034-4041.

29. Burd C. G., Dreyfuss $G$. Conserved structures and diversity of functions of RNA-binding proteins // Science.-1994.-265, N 5172.-P. 615-621.

30. Zarudnaya $M . I$. Co-operative formation of three double helical forms of poly $(\Lambda)$ : proton buffer capacity and electrophoresis data // Conf. on Physics of Biol. systems.-Kyiv, 1998.-P. 52.

31. Brahms J., Michelson A. M., Van Holde $K$. $E$. Adenylate oligomers in single- and double-strand conformation // J. Mol. Biol.-1966.-15, N 2.-P. 467-488.

32. de Melo Neto O. P., Standart $N$., de Sa $C$. M. Autoregulation of poly (A)-binding protein synthesis in vitro // Nucleic Acids Res. - 1995. - 23, N 12.-P. 2198-2205.

УДК $577.323 .7+577.21 .5$

Received 09.09.98 